\title{
Correspondence
}

\section{Immunoprophylaxis of infants born to hepatitis B virus exposed mothers}

Sir,

We hope that the paper by Ewing and Davidson' on a fatal and fulminant hepatitis $B$ virus infection in a 10 week baby born to white parents, with hepatitis $B$ surface antigen ( $\mathrm{HBsAg}$ ) negative father and $\mathrm{HBs} \mathrm{Ag}$ positive, hepatitis $\mathrm{Be}$ antigen $(\mathrm{HBe} \mathrm{Ag})$ negative, $\mathrm{HBe}$ antibody positive mother, should nullify the concept that $\mathrm{HBe}$ antibody positivity in a pregnant mother reduces the apparent risk of perinatal hepatitis B virus transmission. Apart from the present case, there have been at least three similar instances of hepatitis B virus infection in babies of anti-HBe positive mothers. ${ }^{1}$ The mother, in the present case, should have better been tested for hepatitis B virus DNA because this has emerged as a more reliable index of viral replication than $\mathrm{HBeAg}$, DNA polymerase activity, or aminotransferase activity. ${ }^{2}$ The baby blood, like the maternal sample, ${ }^{1}$ should have been tested, for the satisfaction of purists, for IgM antibody to hepatitis B virus core antigen.

Immunoprophylaxis of infants should not only be confined to offsprings of $\mathrm{HBsAg}$ positive mothers but extended to infants born to those who are in the "window phase' with antibody to core antigen but without $\mathrm{HBsAg}$ and antibody to HBsAg. That alone can ensure that fatal and fulminant episodes of hepatitis B virus in the infants born to any low level carriers ${ }^{3}$ among those in "window phase' should stand prevented. Studies with high affinity monoclonal antibody for $\mathrm{HBsAg}^{4}$ should categorise such pregnant women along with $\mathrm{HBsAg} / \mathrm{HBeAg} / \mathrm{hepatitis} \mathrm{B}$ virus DNA positive females as potential dangers for perinatal hepatitis B virus transmission.

$$
\begin{array}{r}
\text { S C Arya, S J Ashraf, and C M Parande } \\
\text { King Fahad Central Hospital and } \\
\text { Gizan General Hospital, } \\
\text { Gizan, } \\
\text { Saudia Arabia }
\end{array}
$$

\section{Drs Ewing and Davidson comment:}

It is well recognised that there is a high risk of transmission of hepatitis $B$ virus to the infant at birth when the mother is both $\mathrm{HBs} \mathrm{Ag}$ and $\mathrm{HBeAg}$ positive, while babies born to HBsAg carrier mothers who have detectable $\mathrm{HBe}$ antibody are at low risk of acquiring hepatitis B virus infection. Thus it was reported ${ }^{5}$ from two West London hospitals that nine of $10(90 \%)$ infants born to $\mathrm{HBeAg}$ positive mothers acquired $\mathrm{HBsAg}$ compared with three of $38(8 \%)$ of those born to $\mathrm{HBe}$ antibody positive mothers. We cannot agree, therefore, with Arya et al that the concept that $\mathrm{HBe}$ positivity reduces the risk of perinatal transmission should be nullified. We agree, however, that there is a case for giving immunoprophylaxis, including passive immunisation with hepatitis $B$ immunoglobulin and active immunisation with hepatitis $B$ vaccine, to all babies whose mothers are $\mathrm{HBsAg}$ positive, irrespective of their $\mathrm{HBeAg}$ or $\mathrm{HBe} A b$ state. It must be noted, however, that supplies of hepatitis B immunoglobulin are limited ${ }^{6}$ and for that reason it may be necessary to give priority to infants of $\mathrm{HBeAg}$ positive mothers.

We accept that of the current tests for hepatitis B infection, that for hepatitis B virus DNA is probably the most reliable index of viral replication. When this child was investigated, however, tests for hepatitis B virus DNA were not available to us and are still not used routinely in most centres. Since our report was published a stored sample of serum from the mother has been examined by Professor A J Zuckerman and Dr T J Harrison at the London School of Hygiene and Tropical Medicine, who have reported that hepatitis B virus DNA is present but just at the limit of detectability.

Arya et al suggest that the infants blood should have been tested for IgM antibody to hepatitis B virus core antigen, 'for the satisfaction of purists'. We cannot understand this comment because such a test would be used to determine whether HBsAg detected in the blood was the result of recent infection or long term carriage and would clearly not be relevant in a 2 month old infant. Moreover, Chen et $\mathrm{ll}^{7}$ were not able to detect IgM core antibody until 9 months of age in any of 86 infants, 31 of whom developed $\mathrm{HBsAg}$, born to HBsAg carrier mothers.

Arya et al refer to the theoretical possibility that $\mathrm{HBsAg}$ negative, core antibody positive mothers may transmit hepatitis B virus infection to their offspring. We are not aware of any evidence that this happens in practice and until there is such evidence we cannot agree that immunoprophylaxis is necessary for these infants.

\section{References}

1 Ewing CI, Davidson DC. Fatal hepatitis B in infant born to a HBsAg carrier with HBeAb. Arch Dis Child 1985;60:265-7.

2 Heijink RA, Boender PJ, Schalm SW, Masurel N. Hepatitis B virus DNA in serum of pregnant women with $\mathrm{HBsAg}$ and HBeAg or antibodies to HBe. J Inf Dis 1984;150:462.

${ }^{3}$ Hoofnagle JH. Serological markers of hepatitis B virus infection. Ann Rev Med 1981;32:1-11.

4 Benn-Porath E, Wands J, Gruia M, Isselbacher K. Clinical significance of enhanced detection of HBsAg by a monoclonal radioimmunoassay. Hepatology 1984;4:803.7.

5 Woo D, Cummins M, Davies PA, Harvey DR, Hurley R, Waterson AP. Vertical transmission of hepatitis B surface antigen in carrier mothers in two West London hospitals. Arch Dis Child 1979;54:670-5.

- Barbara JAJ, Howell DR, Contreras M, et al. Indications for hepatitis B immunoglobulin for neonates of $\mathrm{HBsAg}$ carrier mothers. Br Med J 1984;289:880.

${ }^{7}$ Chen D-S, Sung J-L, Lai M-Y, et al. Inadequacy of immunoglobulin $\mathrm{M}$ hepatitis B core antibody in detecting acute hepatitis B virus infection in infants of HBsAg carrier mothers. J Med Virol 1985;16:309-14. 